\title{
Marka Boyutlarının Marka Evangelizmine Etkisi
}

The Effect of Brand Dimensions on Brand Evangelism

\section{Öz}

Evangelizm kelimesinin saklı tabiatın meydana çıkarmak marka evangelizmini anlamayı daha da kolaylaştıracaktır. Yunanca "iyi haber" ve "ilan etmek" anlamina gelen bu kelime yüzyıllarca ilahiyatla bağdaştırılmıştır. Tüketiciler sahip oldukları baskın hisler ile hayran oldukları markadan yola çıkarak fikirlerini üçüncü kişilere ileterek evangelist olma yoluna girebilirler.

Çalışmanın amacl; marka boyutların oluşturan marka kimliği, marka güveni, marka memnuniyeti ve marka tutkusunun marka evamgelizmini nasıl etkilediğinin ortaya çıkarılmasıdır. Araştırma verileri Erzurum ilinde yaşayan 450 kişi üzerinden yüz yüze anket yöntemi kullanılarak toplanmıştır. 11.03.2020 - 21.03.2020 tarihleri arasında anket uygulanmıştır. Ankete katılanlardan hatalı cevap veren veya eksik yantlanan 12 anketin elenmesi sonucu toplamda 438 anket değerlendirmeye alınmıştır. SPSS 20 ve AMOS 20 programlar kullanılarak elde edilen verilerin analizi gerçekleştirilmiştir. Yapılan analiz neticesinde; marka kimliğinin, marka güveninin ve marka tutkusunun marka evangelizmi üzerinde pozitif yönde etkisinin olduğu belirlenmiştir. Ancak memnuniyet ile marka evangelizmi arasında anlaml herhangi bir ilişki bulunamamıştır. Henüz üzerinde ülkemizde yeterince durulmamış olan marka evangelizmi ile ilgili olan bu çalışmamızın, pazarlama literatüre katkı sağlayacă̆ı ve ayrica uygulayıcilar için de konuya daha fazla dikkat çekilmesine ve öneminin daha iyi anlaşılmasına katkı sağlayacă̆ı düşünülmektedir.

\section{Abstract}

Revealing the hidden nature of the word evangelism will make it easier to understand brand evangelism. Meaning "good news" and "proclaim" in Greek, this word has been associated with theology for centuries. Consumers can start becoming evangelists by conveying their ideas to third parties, based on the brand they admire with their dominant feelings.

The aim of the study; to reveal the effect of forming the brand dimensions brand identification, brand trust, brand satisfaction and brand passion on brand evangelism. The research data were collected from 450

\author{
Ahmet Kirmizibiber \\ Dr., Gümüşhane Üniversitesi, \\ kirmizibiber2585@gmail.com, \\ Orcid No: https://orcid.org/ 0000- \\ 0002-8528-1600

\section{Emel Yildız \\ Doç. Dr., Gümüşhane Üniversitesi, emel.yildiz@yahoo.com, Orcid No: https://orcid.org/0000-0001- 7190-593X}

\section{Article Type / Makale Türü \\ Research Article / Araştırma Makalesi}

\begin{abstract}
Anahtar Kelimeler
Marka Evangelizmi, Marka Kimliği, Marka

Güveni. Marka Tutkusu, Marka Memnuniyeti

\section{Keywords}

Brand Evangelism, Brand Trust, Brand Identification. Brand Satisfaction, Brand Passion
\end{abstract}

\begin{abstract}
Bilgilendirme
Bu çalışma, 03-05 Aralı 2020 tarihleri arasında gerçekleştirilen Uluslararası Bilimsel Araştırmalar Kongresi'nde sözlü bildiri olarak sunulmuştur.
\end{abstract}

JEL Codes: M30,M31, M39

Submitted: $\quad 18 / 02 / 2021$

Accepted: $\quad 12 / 07 / 2021$ people living in Erzurum province using face to face questionnaire method. The survey was conducted between 03.11.2020 - 03.21.2020. A total of 438 questionnaires were evaluated as a result of eliminating 12 questionnaires that gave incorrect or incomplete answers from the respondents. The analysis of the data obtained by using SPSS 20 and AMOS 20 programs was performed. As a result of the analysis; It has been determined that brand identification, brand trust and brand passion have a positive effect on brand evangelism. However, there is no significant relationship between brand satisfaction and brand evangelism. Of our work related to brand evangelism that has been underrated in our country over yet, it will contribute to the marketing literature and also attracting more attention to issues for practitioners and the importance of being expected to contribute to a better understanding.

\section{Giriş}

İşletmelerin tüketicilerin davranışları üzerinde ve pazar üstünlügünü ele geçirmede sahip oldukları etkileyici güçleri dikkate alındığında, tüketiciler ile markalar arasındaki ilişkilerin pazarlama için üzerinde durulması gereken bir araştırma alanı olduğu anlaşılmaktadır (Keller, 2012: 
187). Tüketiciler tarafından kazanılan sadakat, tüketicilerdeki markaya karşı aidiyet hissi ve ötekilerden farklılık düşüncesi işletmeler için önem arz etmektedir (Yıldız ve Avc1, 2019: 208). Güvenilir ve saygı duyulan biri yönlendirme yaparak kolayca tüketicilerin markalara karşı olan tutumlarını ve davranışlarını değiştirebilir. Hemen hemen herkesin bazı markalara karşı aidiyet hissettiği dijital çağda davranışın yönlendirilmesi sıklıkla görülebilir (Shaari ve Ahmad, 2016: 80).

Dijitalleşmenin hızlı bir şekilde devam ettiği pazarlarda rekabet ortamı da hızla değişmektedir. Piyasalara yeni firmaların girmesi oldukça kolaylaşmıştır. Tüketiciler dünyanın dört bir yanında evlerinden çevrimiçi olarak alışveriş yapabilmektedirler. Satın alınabilecek birçok firma ve çok değişik fiyatlar piyasada mevcuttur. Bu ortamda sadık müşteriler oluşturmak yenilerini bulmaktan daha kolaydır. Tüketici bağlılı̆̆ını artırmak ve sürekliliğini sağlamak önemli bir pazarlama stratejisidir. Davranışsal olarak sadakati etkileyen marka evangelizmi pazarlama yöneticileri tarafından doğrudan hedef olarak seçilebilir. Bu sayede işletmeler ürün veya hizmetlerini satın almayı devam etmek isteyen tüketicilere ve kendilerine duygusal olarak bağlanmış kişilere sahip olabilir. Marka evangelistlerini stratejik bir hedeften daha ziyade hedef pazarı olarak kabul etmek rekabet avantaji sağlayacaktır (Cestare, 2018: 73).

Marka evangelizmini konu aldığımız çalışmamız neticesinde marka evangelizminin öneminin daha iyi anlaşılacağı umulmaktadır. Tüketim deneyimindeki rolünün anlaşılması, uygulayıcılar açısından da faydalı olacağı sonucunu gösterir. Çalışmamızın pazarlama literatüründe gerilerde kalan konunun daha fazla yer bulmasına katkı sağlaması ve gelecek çalışmalara yol göstererek fikir vermesi ve onları desteklemesi beklenmektedir.

\section{Marka Evangelizmi}

Bilgi paylaşmak isteyen ortak ilgi alanları ve hedefleri olan kişiler, topluluklar oluşturarak çeşitli iletişim kanalları aracılığıyla etkileşime girerler. Markaya uygun değerler, hayran üyelerinin sosyal kimlik oluşturmasını sağlar. Bu nedenle, topluluk üyeleri marka hayranlarını analiz eder ve yalnızca "mevcudiyet" gerekliliğini değil, aynı zamanda onların "psikolojik" güdü taleplerini de karşılamak için diğer topluluk üyeleri arasında kendi geçmişlerine uygun benzerlikler ve değerler ararlar. Topluluklardaki üyeler bir mesaj yayınladığında veya yanıtladığında, arkadaşlarıyla topluluk üyeleriyle bağlantı kurarlar. Bu nedenle bir marka, hayranların kültürünü etkili bir şekilde tanitmalıdır (Hsu, 2019: 856).

Marka evangelizminin ne anlam ifade ettiğini kavrayabilmek için, önce evangelizm kelimesinin temelini öğrenmek gerekir. Yüzyıllar boyunca teoloji alanında kendisine daha çok yer bulmuştur. Hıristiyan haçlıları ifade etmek için 17. yüzyıl başlarından itibaren kullanılmaya başlanan evangelizm, Koine Grekçesinde "iyi haber getirmenin ödülü" anlamindaki “euangelion" kelimesi ile Yunanca "duyurmak" fiilinden gelmektedir. Hıristiyan inancını yaymak için ulaşabildikleri bütün insanlara ulaşmayı ve inanan insanlar için de duygularının çoğalarak devamlılığını sağlamayı hedefleyen Hıristiyan evangelistler kişisel düşüncelerini duyurmayı ve mesajlarını paylaşmayı kendilerine görev bildiler (Cestare, 2018:2; Chafer, 1911). Oxford sözlüğünde evangelizm, özellikle dini toplantılar yaparak veya radyo veya televizyonda konuşarak ülke içinde seyahat ederek insanları Hıristiyan olmaya ikna etmeye çalışmanın bir uygulaması olarak tanımlanmaktadır. Dolayısıyla, literatürde bir markayı savunmaya yönelik derin bir bağlılı̆̆ı tanımlamak için bu terimi ödünç alıp kullanmak oldukça mantıklıdır (Mamesah, vd., 2020: 12).

Son yıllarda ortaya çıkan "Marka Evangelizmi" ifadesi, tüketicilerin misyoner gibi sergiledikleri tutkulu davranışları tanımlamak için kullanılmaktadır (Matzler, vd., 2007: 27). Tüketicilerin tutkunu oldukları marka için; satın alma niyetini artırma, pozitif düşünceleri yayma ve diğer markaları küçük düşürme gibi ikna çabaları ve destekleri mevcuttur (Becerra ve Badrinarayanan, 2013: 372). Literatürde mevcut olan diğer olumlu marka ilişkileri biçimlerinin aksine, marka evangelizmi kavramı açıkça rakip markaları karalamayı içerir (Marticotte, vd., 2016: 539). Geleneksel pazarlamanın ulaştırabileceği marka düşüncelerini, özelliklerini ve yapısını marka evangelistleri de çevrelerine, arkadaşlarına, ailelerine ve meslektaşlarına istekli olarak eşsiz bir biçimde iletebilirler (Smilansky, 2009: 5; Riivits-Arkonsuo, vd., 2014: 6). Her ne kadar ağızdan ağıza pazarlamaya benzese de aslında farklıdır. Çünkü ağızdan ağıza pazarlamada ikna etme gibi bir amaç yoktur ve 
tüketiciler kendilerinde böyle bir zorunluluk hissetmezler. Ancak marka evangelizminde markanın gönüllü ücretsiz sözcüsü olan evangelistler, çevrelerini ikna etmek için çaba sarf ederler ve bunu kendilerinde görev olarak görürler. Evangelistlerin iletişimde kullandıkları yöntemler, üçüncü kişilerin fikirlerini değiştirme niyetinde olmasından dolayı nasihat şeklinde de nitelendirilebilir (Doss, 2010: 13).

\section{Marka Boyutları}

Çalışmamızın bu bölümünde, araştırmamız için ele aldığımız marka boyutlarından 4 tanesinin tanımları ve açıklamaları yer almaktadır. Bu boyutlar; marka güveni, marka memnuniyeti, marka kimliği ve marka tutkusudur.

\subsection{Marka Güveni}

"Güven" kavramı aslında marka güveni tanımı için çok önemlidir ve marka güveni için gerekli olan iki temel bileşen mevcuttur. Bunlar; güvenilirlik ve uzmanlıktır. Güvenilirlik, tüketicinin samimi ve dürüst bir şekilde kaliteli performans sağlayan markaya duyduğu güven anlamına gelir. Uzmanlık ise, bir markanın yetenekli ve bilgili olarak algılanma derecesidir ve ürün / hizmet kategorisindeki deneyim veya eğitimden gelir (Sung ve Kim, 2010: 644). Güven sayesinde tüketici kendini özellikle savunmasız hissettiği bir ortamda risk veya belirsizlikle baş edebilir, çünkü tüketici, güvenilen markaya güvenilebileceğini bilir (Chaudhuri \& Holbrook, 2002: 41).

Bir markanın müşterileri üzerinde oluşturmuş olduğu beklentileri yerine getireceğini taahhüt etmesi en büyük vaatlerindendir. Marka güveni, markaya sadık olacak müşteri elde edebilmek için destekçi olan güçlü bir etmendir. Vaatlerini yerine getirebilen ve amaçlarının öncelikle müşteri memnuniyeti olduğu kanısını tüketicilerde oluşturabilen markalar ile tüketiciler arasında güven hissi oluşturulabilir (Ahmed, vd., 2014: 309). Güven üzerine inşa edilmiş karş1lıklı ilişkide müşterilerde marka ile olan iletişimlerinden memnun oldukları için ve iletişime geçme konusunda istekli oldukları için marka güvenini oluşturulan stratejik ortaklığın temel taşı gibi düşünebiliriz. Bu nedenle markalar evengelist düzeyde müşteriler yakalayabilmek ve kendi menfaatleri için onların harekete geçmelerini sağlayabilmek için, öncelikle onlar üzerinde güven duygusunu oluşturmaları gerekir (Riorini ve Widayati, 2015: 35).

\subsection{Marka Memnuniyeti}

Tüketici her zaman, ihtiyaç ve isteklerinin karşılanmasına yol açan işlevsel, sembolik, duygusal, bilgi verici ve durumsal faydalar sağlayabilecek bir ürün arar (Tran, vd., 2020: 214). Song ve arkakaşları (2011), bir ürün veya hizmete ilişkin memnuniyet düzeyi, müşterinin yaşadığ1 memnuniyet veya memnuniyetsizlik düzeyine göre belirlendiğini ifade etmiştir. Memnuniyet, bir satın alma işlemi yaptıktan sonra müşterilerin satın alma ödülleri ve maliyeti arasında karşılaştırılmasından kaynaklanan bir sonuçtur (Jamshidi ve Rousta, 2021: 154).

Bir markadan memnun kalan tüketiciler gelecekte aynı markayı tekrar kullanmayı tercih ederler (Mabkhot, vd., 2016: 90). Marka ile özdeşleşmeye ve yalnızca bir savunucu olmayıp evangelisti olmasına da neden olan marka memnuniyeti, markalar için oldukça öneme sahiptir (Doss, 2010: 16). Marka memnuniyeti bir bütün olarak, temelinde kullanıcıların elde ettikleri gerçek ürün veya hizmet deneyimi ile bekledikleri değerler arasındakini mukayese etmesine dayanır ve tüketicinin belleğindeki tutumları kapsar (Chen, vd., 2020: 4).

\subsection{Marka Kimliği}

Firmanın müşterileri, rakipleri ve iş ortamının tam olarak anlaşılmasına dayanmaktadır (Ghodeswar, 2008: 4). Özel olarak marka kimliği, bir markaya yönelik tüketicilerde oluşan aidiyeti idrak etme, kendisi gibi hissetme veya markaya psikolojik olarak değer verme olarak anlatılabilir (Lam, vd., 2010: 129). Aaker'a (1991) göre kurumsal marka kimliği, hedefle fonksiyonel, duygusal veya kendini ifade eden faydalar yoluyla ilişki kuran benzersiz marka ilişkileri kümesidir.

Markanın kendini ifade etme gücü ve markayla daha iyi müşteri bütünlüğü için marka kimliği yapısına özel önem verilmelidir, bu da sonunda markaya duygusal bağlar, güven ve tutku oluşturulmasına yol açar (Hajibabei ve Esmailpur, 2018: 63). Bu anlayış ile markaya karşı psikolojik bir bağ kurulmuş olur ve uzun vadede getiriler sağlaması ile davranışın tekrarlanmasında etkisinin bulunması nedeniyle de oldukça öneme sahiptir (Rather, 2018: 489). Bir firma, marka kimliği 
aracılığıyla kişiliğini ve farklılığını herkese aktarmaya çalışır (Srivastava, 2011: 341). Belirli marka ile özdeşleşen tüketicilerde; markaya oldukça iltimas göstermesi, markaya saygı duyması ve farkında olmadan markaya yönelik faydalı çalışmalar yapması sonuç olarak beklenir (Kuenzel ve Halliday, 2008: 294). Firmanın marka kimliği ve temsil ettiği şey firmanın en önemli varlıkları arasındadır ve rekabet avantajı oluşturmak ve performansı artırmak için bir temel sağlar (Craig, vd., 2008: 364). Markaya anlam ve amaç vererek marka değeri oluşturmaya ve finansal faydalar elde etmeye yardımcı olur (Pusa ve Uusitalo, 2014: 19).

\subsection{Marka Tutkusu}

Tüketiciler için ne derece önemli olursa olsun, tüketicilerin ona sahip olmayı istemesinde veya ürünü kullanmayı arzu etmesinde etkili olan marka tutkusu, markaya saygınlık kazandırabilmek için vazgeçilemez derecede öneme sahip bir konumdadır (Kim., vd., 2020: 2). Tutkulu tüketiciler markaya karşı güçlü bir bağl1lığa sahiptirler (Füller, vd., 2008: 612). Marka tutkusunda hakim olan tutku, bireyler arasında yaşanan ilişkilerde yer aldığı şekilde farklı bir bireye değildir, mal ve hizmete yada markalara karşıdır. Tüketen ile ürün veya hizmetin markası arasındaki ilişkide tutku yüksek seviyelerde ise, tüketici markaya karşı yüksek düzeylerde duygusal bir bağa sahip olacak ve markaya özlem duyacaktır. Bunun tam tersi bir durumda yani markanın yoksunluğunun mevcut olduğu durumunda ise, tüketici markanın eksikliğini hissedecektir (Matzler, vd., 2007: 26).

Tutku, bir markaya yönelik olumlu bir uyarılma niyetini ve duygularını yansıtır, diğer bir deyişle marka tutkusu, bir markanın ciddi bir ihtiyaç ve kullanım duygusu anlamına gelir (Brown ve Alnawas, 2016: 2785). Markalara karşı tutkuyla bağlı müşteriler, markaların varlığıyla aktif bir şekilde etkileşimde bulunur ve markanın topluluklarında aktif olma eğilimindedirler (Pourazad, vd., 2015: 7).

Bu çalışmanın amacını kısaca ifade etmek gerekirse, markayı kabullenme ve markayı savunma tutumlarının bir sonucu olarak tanımlanan tüketici ile marka arasındaki ilişkilerin marka evangelizmini nasıl etkilediğine kaynaklık etmektir.

\section{Literatür ve Hipotezler}

Geçmiş yıllarda yapılan çalışmalara bakıldığında (Matzler, vd., 2007; Doss, 2010; Becerra ve Badrinarayanan, 2013; Riorini ve Widayati, 2015; Shaari ve Ahmad, 2016; Mehran, vd., 2017; Y1lmaz ve Aykaç, 2018; Anggarini, 2018) marka evangelizmi ve etkilendiği değişkenler hakkında araştırmalar yapıldığı görülmektedir. Matzler ve arkadaşları (2007) çalışmalarını tutkulu otomobil sahipleri üzerinde gerçekleştirmiş olup; kişilik, tüketici tutkusu ve marka evangelizmi arasındaki ilişkinin anlaşılmasını geliştirmeyi amaçlamışlardır. Elde ettikleri bulgulara göre, marka tutkusunun marka evangelizmi üzerinde pozitif etkisinin olduğunu ispatlamıştır. Daha fazla dişa dönük tüketicinin, tutkulu tüketiciler olma ve marka evangelizmine katılma olasılığının daha yüksek olduğunu göstermişlerdir. Marka evangelizmi olgusunu ve bir tüketicinin marka evangelisti olmasına dahil olan boyutları daha iyi anlamayı hedefleyen Doss (2010) yaptı̆g çalışmasında; tüketici ile marka kimliği arasındaki bağ ne kadar güçlüyse, marka evangelizminin de o kadar güçlü olduğunu, tüketici-marka özdeşleşmesi ve fikir liderliğinin marka evangelizmine yol açan kavramlar olduğu buldu. Marka güveni ve marka kimliğinin marka evangelizmi üzerindeki etkisini inceleyen Becerra ve Badrinarayanan (2013), tüketicilerin bir markayla olan ilişkisinin doğasının, yoğun bir marka destek davranışı biçimi olan marka evanjelizmini nasıl etkilediğini ortaya çıkarmayı amaçlamıştır. Bulgular, tüketici-marka ilişkilerinin, farklı şekillerde de olsa dahi, marka evangelizmini etkilediğini ortaya koymuştur. Riorini ve Widayati (2015)'nin çalışmalarındaki amaçları, marka ilişkisi, marka güveni, marka kimliği, marka ilgisi, marka taahhüdünün marka evangelizmine etkisini analiz etmekti. En az 12 ay boyunca bankacılık hizmetlerinden yararlanmış 200 ticari banka müşteri üzerine uygulama yapmışlardır. Elde ettikleri sonuçlara göre, müşterilerin bankalarına karşı gittikçe artan bir şekilde bir ilişki, güven, özdeşleşme, katılım ve marka bağlılıklarının olduğu bunun sonucunun da markaya karşı olumlu düşüncelerinin, satın alma niyetlerinin ve üçüncü kişilere referanslar verme niyetinin giderek artacağını ifade etmişlerdir. Ayrıca marka taahhüdünün marka evangelizmi üzerinde en baskın etkiye sahip olan değişken olduğunu bildirmişlerdir. Üyelerin marka topluluğu bağlılığının, ekstra rol davranışı olarak görülen 
marka evangelizmini nasıl etkilediğine dair anlayışı genişletmeye çalışan Shaari ve Ahmad (2016), sonuç olarak, çevrimiçi marka topluluğuna duyulan güvenin ve marka topluluğuna bağlılığının, marka evangelizmini önemli ölçüde etkilediğini göstermiştir. Mehran ve meslektaşlarının (2017) yapmış oldukları çalışmanın amacı, müşteri-grup ilişkilerinin ve hizmet kalitesinin marka evangelizmini nasıl etkilediğini ve daha da önemlisi; marka sevgisinin, marka güveninin, hizmet kalitesinin, marka kimliğinin marka evangelizmi üzerindeki 1lımlı etkisini incelemektedir. Çalışma Multan'da hizmet veren farklı restoranların marka bilinci olan 400 müşterisi üzerinde gerçekleştirilmiştir. Araştırmanın bulguları, marka güveni, hizmet kalitesi ve marka kimliğinin marka evangelizmi üzerindeki etkilerinin önemli olduğunu ortaya koymuştur. Ayrıca marka sevgisinin de bu değişkenler arasındaki ilişkiler üzerinde olumlu etkiye sahip olduğu belirtilmiştir. İşletmelerin devamlı olarak rekabette avantaj kazanabilmeleri için evangelist düzeyde müşteri elde edebilmek amacıyla dikkat etmeleri gereken noktaları ifade edebilmek amacıyla çalışma yapan Yılmaz ve Aykaç (2018), marka imajının marka evangelizmi üzerindeki olumlu etkisinin var olduğunu ve marka güveninin bu etkiyi iyice artırabileceğini belirtmiştir. Son olarak marka evangelizmini inceleyecek bir tüketicinin marka evangelisti olmasının hangi boyutlarda olduğunu anlamaya yönelik çalışma yapan Anggarini (2018) verilerini, Endonezya'da Apple iPhone'u en az 6 aydır kullanan 468 katılımcıya çevrimiçi anketler uygulanarak elde etmiştir. Elde ettiği bulgular, marka memnuniyetinin, tüketici-marka kimliğinin, marka belirginliğinin, marka güveninin ve fikir liderliğinin marka evangelizmine olumlu etkisi olduğunu göstermiştir.

Yukarıda kısaca özetlenen literatürden yola çıkarak çalışmamız için aşağıdaki hipotezler oluşturulmuştur.

Hipotez $1\left(\mathbf{H}_{1}\right)$ : Marka güveninin marka evangelizmi üzerinde pozitif yönde etkisi vardır.

Hipotez $\mathbf{2}\left(\mathbf{H}_{\mathbf{2}}\right)$ : Marka tutkusunun marka evangelizmi üzerinde pozitif yönde etkisi vardır.

Hipotez $3\left(\mathbf{H}_{3}\right)$ : Marka kimliğinin marka evangelizmi üzerinde pozitif yönde etkisi vardır.

Hipotez $4\left(\mathbf{H}_{4}\right)$ : Marka memnuniyetinin marka evangelizmi üzerinde pozitif yönde etkisi vardır.

\section{Uygulama}

Çalışmanın bu bölümünde sırasıyla; araştırmanın amacından, kapsamından ve sınırlarından, metodolojisinden, modelinden ve son olarak verilerin analizinden ve yönteminden bahsedilecektir.

\subsection{Araştırmanın Amaci}

Marka evangelizmin tanıtımının yapılması ve yeterince bilgi sahibi olunmayan önemini ortaya koyarak, marka tutkusu, marka memnuniyeti, marka güveni ve marka kimliğinin marka evangelizmi üzerindeki pozitif etkisinin kanıtlanması çalışmanın amacını oluşturmaktadır.

\subsection{Araştırmanın Yöntemi}

Erzurum ilinde ikamet eden bireyler araştırmanın kapsamını oluşturmaktadır. Araştırmaya katılan tüketicilerden ilk önce, kendilerini olumlu sözcüsü olarak gördükleri ve düşüncelerini son altı ay içinde çevreleriyle paylaştıkları bir markayı anket formuna yazmaları istenmiş olup, daha sonra geri kalan soruları belirttikleri markayı düşünerek yanıtlamaları istenmiştir.

Tesadüfi olmayan örnekleme yöntemlerinden "kolayda örnekleme yöntemi", örnekleme yöntemi için kullanılmıştır. Toplam da uygulanan 450 anketten; eksik, hatalı ve yanlış olanların elenmesi neticesinde 438 anket değerlendirmeye tabi tutulmuştur.

Anket formuna son şeklini verebilmek, anket formunda kullanılan ölçeklerin yeterince açık ve anlaşılır olup olmadığını test edebilmek ve ortaya çıkabilecek eksikliklerin giderilebilmesi için verilerin toplanmasına başlamadan önce 20 kişiye ön test uygulanmıştır. Yapılan öntest sonucu elde edilen öneriler, eleştiriler ve görüşler doğrultusunda anket formu tekrar gözden geçirilerek nihai şekli kazandırılmıştır.

Araştırmanın veri toplaması aşamasında kullanılan yüz yüze anket formu, 3 grup sorudan oluşmaktadır. Ankete katılan tüketicilerden kendilerini olumlu sözcüsü olarak gördükleri ve fikirlerini son altı ay içerisinde çevreleriyle paylaştıkları herhangi bir markanın ismi belirtmeleri şeklindeki soru 1. grupta yer almaktadır. 2. grupta ise ankete katılan tüketicilerin marka boyutları (marka kimliği, marka güveni, marka memnuniyeti ve marka tutkusu) ile marka evangelizmi hakkındaki fikirlerini ölçmek için 5'li Likert ölçeğinde hazırlanmış ifadeler yer almaktadır. Son 
grupta ise ankete katılan tüketicilerin demografik özelliklerini belirlemek amacıyla hazırlanmış sorular yer almaktadir.

Marka evangelizmi Cestare (2018), Riorini ve Widayati (2015) ile Matzler, vd. (2007) çalışmalarından yola çıkılarak 6 ifadeyle, marka güveni Becerra ve Badrinarayanan (2013) ile Riorini ve Widayati (2015) çalışmalarından yola çıkarak 5 ifadeyle, marka kimliği Becerra ve Badrinarayanan (2013) ile Doss (2010) çalışmalarından yola çıkarak 5 ifadeyle, marka tutkusu Matzler, vd. (2007) çalışmasından yola çıkarak 6 ifadeyle ve marka memnuniyeti ise Doss (2010) çalışmasından yola çıkarak 4 ifadeyle ölçümü yapılmıştır.

Anket aracılığıyla toplanan veriler SPSS 20.0 ve AMOS 20 istatistik programları kullanılarak analizi yapılmıştır. Veriler üzerinde faktör analizi yapılarak yapısal eşitlik modeli kurulmuştur.

\subsection{Araştırmanın Modeli}

Çalışmanın modeli amaç doğrultusunda literatürden yola çıkarak Şekil 1'de göründüğü gibi hazırlanmıştır. Model; Matzler (2007), Doss (2010), Becerra ve Badrinarayanan (2013), Balıkçıŏlu ve Oflazoğlu (2015), Riorini ve Widayati (2015) Yılmaz ve Aykaç (2018) ile Cestare (2018)'nin yapmış oldukları çalışmalardan esinlenerek hazırlanmıştır.

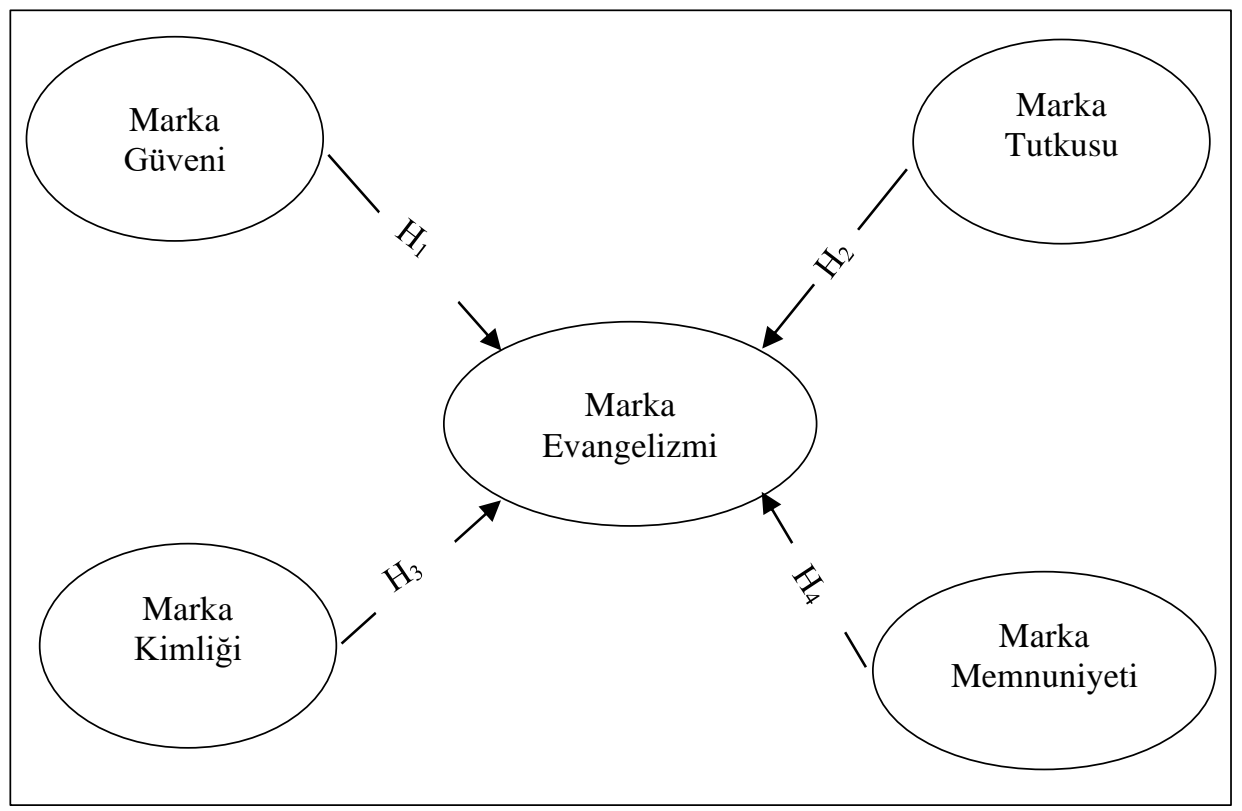

Şekil 1. Araştırma Modeli

\subsection{Bulgular}

4.4.1. Araştırma Örneğinin Demografik Özellikleri

Tablo 1. Katılımcıların Demografik Özellikleri

\begin{tabular}{|c|c|c|c|c|c|c|c|}
\hline \multicolumn{8}{|c|}{ Demografik Özellikler } \\
\hline & & $\begin{array}{l}\text { Frekans } \\
\text { (f) }\end{array}$ & $\begin{array}{c}\text { Yüzde } \\
(\%)\end{array}$ & & & $\begin{array}{l}\text { Frekans } \\
\text { (f) }\end{array}$ & $\begin{array}{c}\text { Yüzde } \\
(\%)\end{array}$ \\
\hline \multirow{3}{*}{ Cinsiyet } & Erkek & 230 & 52,5 & \multirow{3}{*}{$\begin{array}{l}\text { Medeni } \\
\text { Durum }\end{array}$} & Evli & 232 & 53,0 \\
\hline & Kadın & 208 & 47,5 & & Bekâr & 206 & 47,0 \\
\hline & Toplam & 438 & 100 & & Toplam & 438 & 100 \\
\hline \multirow{3}{*}{ Yaş } & 17 ve altı & 21 & 4,8 & \multirow{3}{*}{ Meslek } & Memur & 104 & 23,7 \\
\hline & $18-28$ & 74 & 16,9 & & İşçi & 74 & 16,9 \\
\hline & $29-39$ & 139 & 31,7 & & Emekli & 31 & 7,1 \\
\hline
\end{tabular}




\begin{tabular}{|c|c|c|c|c|c|c|c|}
\hline & $40-50$ & 107 & 24,4 & & Özel Sektör & 78 & 17,8 \\
\hline & $51-61$ & 66 & 15,1 & & Öğrenci & 85 & 19,4 \\
\hline & 62 ve üstü & 31 & 7,1 & & Ev Hanımı & 53 & 12,1 \\
\hline & Toplam & 438 & 100 & & Diğer & 13 & 3,0 \\
\hline \multirow{7}{*}{$\begin{array}{l}\text { Eğitim } \\
\text { Durumu }\end{array}$} & İlkokul & 10 & 2,3 & & Toplam & 438 & 100 \\
\hline & Ortaokul & 15 & 3,4 & \multirow{6}{*}{ Gelir } & 2000 ve alt1 & 109 & 24,9 \\
\hline & Lise & 126 & 28,8 & & $2001-4000$ & 116 & 26,5 \\
\hline & Önlisans & 108 & 24,7 & & $4001-6000$ & 139 & 31,7 \\
\hline & Lisans & 143 & 32,6 & & $6001-8000$ & 51 & 11,6 \\
\hline & Lisansüstü & 36 & 8,2 & & 8001 ve üzeri & 23 & 5,3 \\
\hline & Toplam & 438 & 100 & & Toplam & 438 & 100 \\
\hline
\end{tabular}

Çalışmaya dahil edilen katılımcıların \%47,5 (208 katılımcı)'i kadın, \%52,5 (230 katılımcı)'i erkektir. Genel olarak bakıldığında çalışmaya katılanların çoğunluğunu; evli (\%53 - 232 katılımc1), 29 - 39 yaş aralığında (\%31,7 - 139 katılımc1), memur (\%23,7 - 104 katılımcı), lisans seviyesi eğitim düzeyine sahip (\%32,6 - 143 katılımc1) ve 4001 TL - 6000 TL gelir aralığına sahip (\%31,7 - 139 katılımc1) kişiler oluşturmuştur.

\subsubsection{Güvenilirlik ve Geçerlilik Analizi}

Araştırma ölçeklerinin güvenilirliğini ölçmek için cronbach alpha değerleri incelenmiştir. Elde edilen sonuçlar Tablo 2'de gösterilmektedir.

Tablo 2. Ölçeklere Ait Güvenilirlik Analizi Sonuçları

\begin{tabular}{|l|c|c|}
\hline Ölçekler & Madde Sayıs & Cronbach Alpha \\
\hline Marka Güveni & 5 & 0,827 \\
\hline Marka Kimliği & 5 & 0,832 \\
\hline Marka Tutkusu & 6 & 0,845 \\
\hline Marka Memnuniyeti & 4 & 0,848 \\
\hline Marka Evangelizmi & 6 & 0,853 \\
\hline Bütün Ölçekler & 26 & 0,910 \\
\hline
\end{tabular}

Tablo 2' de görüldü̆ğü üzere marka güveni ölçeğinin güvenirliliği 0,827, marka kimliği ölçeğinin güvenirliliği 0,832, marka tutkusu ölçeğinin güvenilirliği 0,845, marka memnuniyeti ölçeğinin güvenilirliği 0,848 ve marka evangelizmi ölçeğinin güvenilirliği 0,853 olarak bulunmuştur. Araştırmada yer alan bütün ölçekleri analize dahil ettiğimizde ise cronbach alpha değeri 0,910 olarak bulunmuştur. Dolayısıyla ölçeklerin yüksek derecede güvenilir olduğunu söylemek mümkündür.

Araştırmada ele alınan değişkenlerin seçilen örneklem ile uyumlu olup olmadığını kontrol etmek amacıyla ilk önce açıklayıcı faktör analizi daha sonra doğrulayıcı faktör analizi yapılmıştır.

Tablo 3. Açıklayıcı Faktör Analizi Sonuçları

\begin{tabular}{|c|c|c|c|c|}
\hline \multicolumn{2}{|l|}{ Değişkenler } & Faktör Yükleri & Varyans Yüzdesi & Özdeğeri \\
\hline \multirow{6}{*}{ 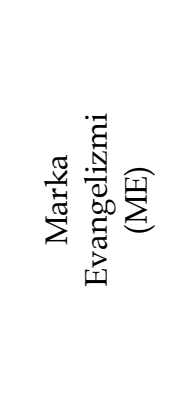 } & ME1 & 0,690 & \multirow{6}{*}{31,125} & \multirow{6}{*}{8,093} \\
\hline & ME2 & 0,779 & & \\
\hline & ME3 & 0,692 & & \\
\hline & ME4 & 0,703 & & \\
\hline & ME5 & 0,653 & & \\
\hline & ME6 & 0,576 & & \\
\hline
\end{tabular}




\begin{tabular}{|c|c|c|c|c|}
\hline \multirow{6}{*}{ 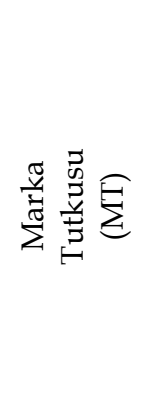 } & MT1 & 0,639 & \multirow{6}{*}{11,174} & \multirow{6}{*}{2,905} \\
\hline & MT2 & 0,733 & & \\
\hline & MT3 & 0,777 & & \\
\hline & MT4 & 0,785 & & \\
\hline & MT5 & 0,690 & & \\
\hline & MT6 & 0,594 & & \\
\hline \multirow{4}{*}{ 总 } & MM1 & 0,718 & \multirow{4}{*}{7,954} & \multirow{4}{*}{2,068} \\
\hline & MM2 & 0,837 & & \\
\hline & MM3 & 0,819 & & \\
\hline & MM4 & 0,704 & & \\
\hline \multirow{5}{*}{ 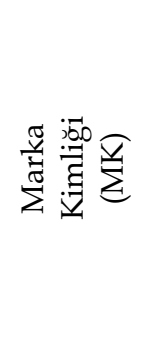 } & MK1 & 0,501 & \multirow{5}{*}{6,759} & \multirow{5}{*}{1,757} \\
\hline & MK2 & 0,706 & & \\
\hline & MK3 & 0,793 & & \\
\hline & MK4 & 0,772 & & \\
\hline & MK5 & 0,684 & & \\
\hline \multirow{5}{*}{ 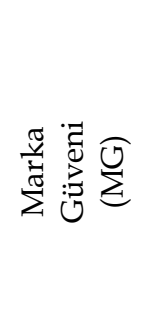 } & MG1 & 0,403 & \multirow{5}{*}{4,921} & \multirow{5}{*}{1,279} \\
\hline & MG2 & 0,405 & & \\
\hline & MG3 & 0,583 & & \\
\hline & MG4 & 0,704 & & \\
\hline & MG5 & 0,707 & & \\
\hline
\end{tabular}

Gerçekleştirilen açıklayıcı faktör analizinde 0,50'nin altında faktör yükü alan değişkenler (MG1 ve MG2) değerlendirmeden çıkarılmıştır. Yapılan analiz sonucunda; bütün ölçeklerin alpha değeri 0,910 çıkarken, Kaiser-Meyer-Olkin (KMO) örneklem yeterlilik ölçütü değeri 0,871 ve Barlett Küresellik Testi değeri de p<0,000 ve 5955,660 çıkmıştır. 1'den büyük özdeğere sahip toplam da 5 faktör türetilmiştir. "Marka Evangelizmi" 1. faktörü, "Marka Tutkusu" 2. faktörü, "Marka Memnuniyeti" 3. faktörü, "Marka Kimliği" 4. faktörü ve "Marka Güveni" de 5. faktörü oluşturmuştur. Ortaya çıkan faktörlerin toplamı varyansın \%61,933'ünü açıklamaktadır.

Daha sonra gerçekleştirilen doğrulayıcı faktör analizi sonuçlarına baktığımızda, çalışmada uygulanan ölçek toplamda 5 faktör ile oluşturulan bir yapıda ele alınmıştır. Araştırması yapılan yapıda; marka evangelizmi 6 madde ile, marka tutkusu 6 madde ile, marka güveni 3 madde ile, marka kimliği 5 madde ile ve marka memnuniyeti de 4 madde ile ölçekte yer almıştır. Analiz sonucu elde edilen model uyum kriterleri dikkate alınmış ve sonuçta; RMSEA: 0,091, CMIN: 1122,826, DF: 242, p<0,001, CMIN/DF: 4,640, değerleri ortaya çıkmıştır. Görüldüğü üzere ortaya çıkan model uyum değerleri kabul edilebilir sinırların uzağındadır. Bu nedenle modifikasyon indeksleri üzerinden yeniden analiz yapılarak sonuçlar revizyon edilmiştir. Yapılan modifikasyonlar neticesinde; RMSEA: 0,075, CMIN: 821,552, DF: 239, p<0,001, CMIN/DF: 3,437 değerleri elde edilmiştir. Ortay çıkan yeni sonuçlar kabul edilebilir sınırlar içerisindedir. Dolayısıyla modelin uyum düzeyine sahip olduğunu söyleyebiliriz. 


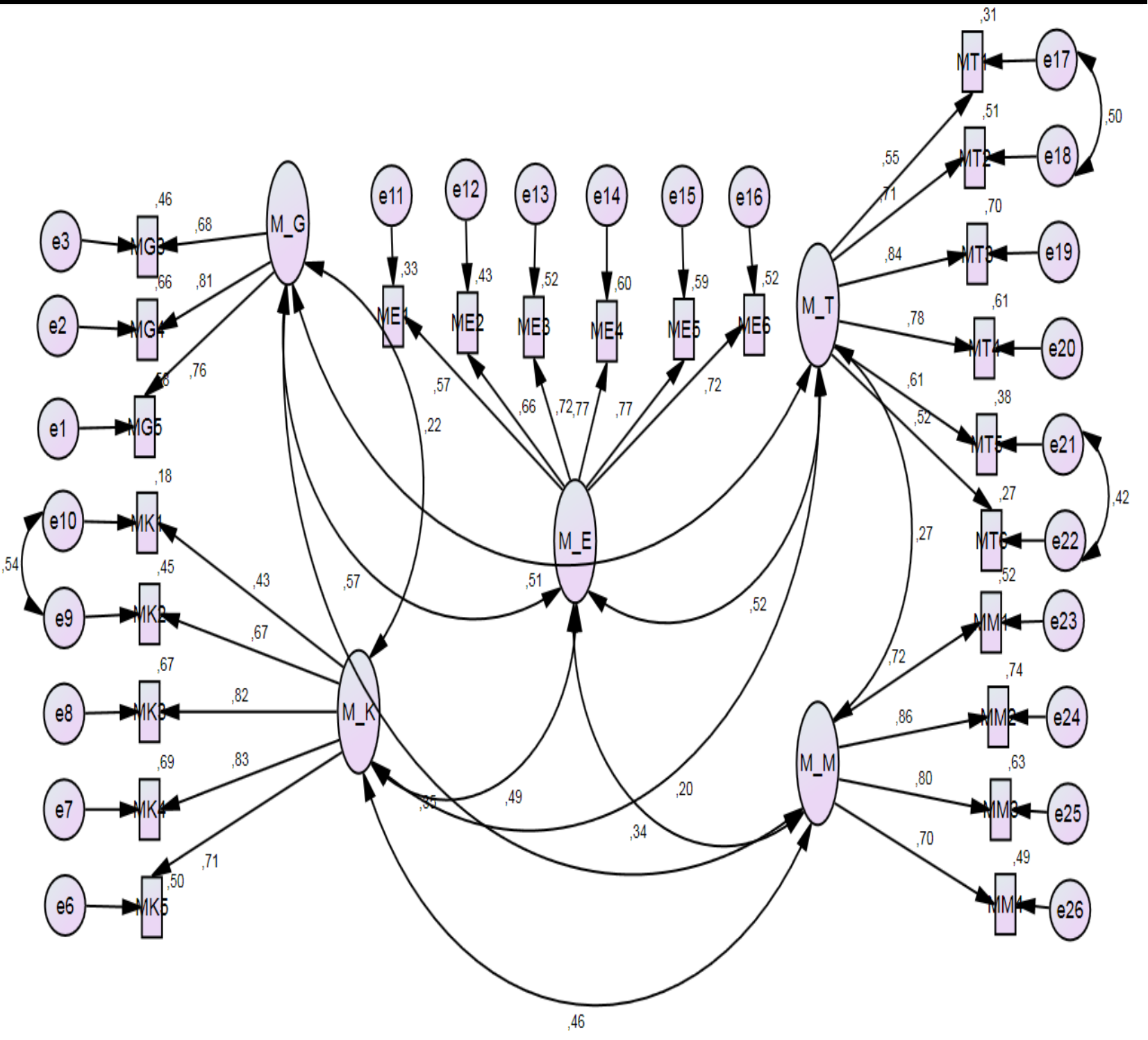

Şekil 2. Standart Yol Katsayıları 


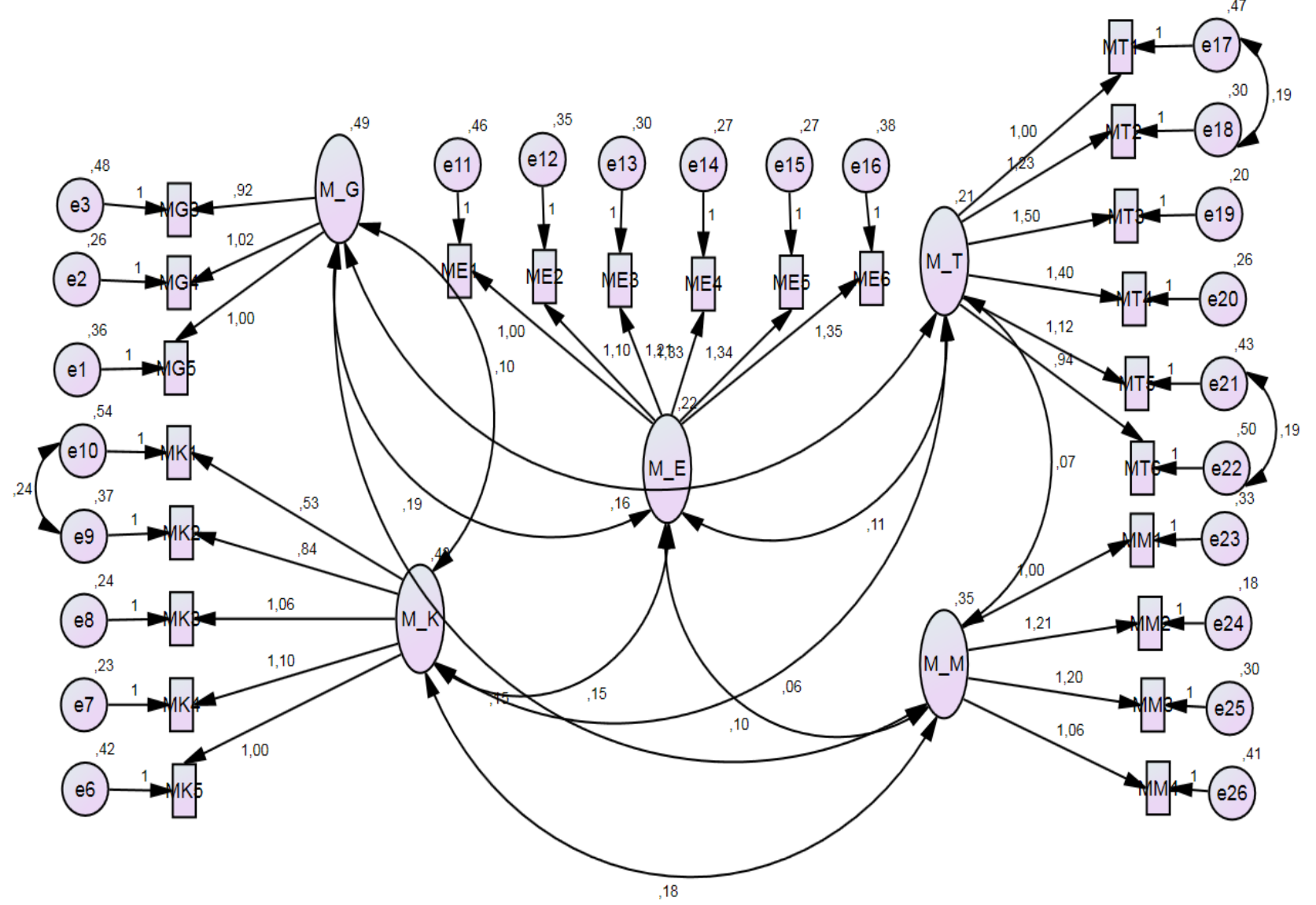

Şekil 3. Standart Olmayan Yol Katsayıları

Doğrulayıcı faktör analizinde;

Marka güveni altında yer alan tüm maddelere ait yol katsayıları istatistiksel olarak anlamlı bulunmuştur. MG3 için elde edilen yol katsayısı $\beta_{0}: 0,681$, MG4 için $\beta_{0}: 0,813$ ve MG5 için de $\beta_{0}: 0,761$ olarak elde edilmiştir. Standartlaştırılmış yol katsayılarına bakıldığında marka güveni üzerinde en fazla etkiye sahip olan maddenin MG4 olduğu görülmektedir $\left(\beta_{0}: 0,813\right)$.

Marka kimliğ $i$ altında yer alan tüm maddelere ait yol katsayıları istatistiksel olarak anlamlı bulunmuştur. MK1 için elde edilen yol katsayısı $\beta_{0}: 0,425$, MK2 için $\beta_{0}: 0,670$, MK3 için $\beta_{0}: 0,816$, MK4 için $\beta_{0}: 0,831$ ve MK5 için de $\beta_{0}: 0,710$ olarak elde edilmiştir. Standartlaştırılmış yol katsayılarına bakıldığında marka kimliği üzerinde en fazla etkiye sahip olan maddenin MK4 olduğu görülmektedir $\left(\beta_{0}: 0,831\right)$.

Marka evangelizmi altında yer alan tüm maddelere ait yol katsayıları istatistiksel olarak anlamlı bulunmuştur. ME1 için elde edilen yol katsayısı $\beta_{0}: 0,572$, ME2 için $\beta_{0}: 0,658$, ME3 için $\beta_{0}: 0,718$, ME4 için $\beta_{0}: 0,773$, ME5 için $\beta_{0}: 0,771$ ve ME6 için de $\beta_{0}: 0,720$ olarak elde edilmiştir. Standartlaştırılmış yol katsayılarına bakıldığında marka kimliği üzerinde en fazla etkiye sahip olan maddenin ME4 olduğu görülmektedir $\left(\beta_{0}: 0,773\right)$.

Marka tutkusu altında yer alan tüm maddelere ait yol katsayıları istatistiksel olarak anlaml bulunmuştur. MT1 için elde edilen yol katsayısı $\beta_{0}: 0,554$, MT2 için $\beta_{0}: 0,714$, MT3 için $\beta_{0}: 0,836$, MT4 için $\beta_{0}: 0,781$, MT5 için $\beta_{0}: 0,615$ ve MT6 için de $\beta_{0}: 0,520$ olarak elde edilmiştir. Standartlaştırılmış yol katsayılarına bakıldığında marka kimliği üzerinde en fazla etkiye sahip olan maddenin MT3 olduğu görülmektedir ( $\left.\beta_{0}: 0836\right)$.

Marka memnuniyeti altında yer alan tüm maddelere ait yol katsayıları istatistiksel olarak anlamlı bulunmuştur. MM1 için elde edilen yol katsay1s1 $\beta_{0}: 0,719$, MM2 için $\beta_{0}: 0,858$, MM3 için $\beta_{0}: 0,795$ ve MM4 için de $\beta_{0}: 0,699$ olarak elde edilmiştir. Standartlaştırılmış yol katsayılarına bakıldığında marka güveni üzerinde en fazla etkiye sahip olan maddenin MM2 olduğu görülmektedir $\left(\beta_{0}: 0,858\right)$. 
Aşağıda gösterilen Şekil 2 ve Şekil 3'te gerçekleştirilen doğrulayıcı faktör analizi sonucu elde edilen standart yol katsayıları ve standart olmayan yol katsayıları yer almaktadır.

Tablo 4. Doğrulayıcı Faktör Analizi Sonuçları

\begin{tabular}{|c|c|c|c|c|c|c|c|}
\hline Madde & Path & Faktör & $\beta_{0}$ & $\beta_{1}$ & S.E. & C.R. & $\mathrm{P}$ \\
\hline MG5 & $<---$ & M_G & 0,761 & 1 & & & \\
\hline MG4 & $<---$ & M_G & 0,813 & 1,023 & 0,071 & 14,503 & $<0,001$ \\
\hline MG3 & $<--$ & M_G & 0,681 & 0,918 & 0,071 & 12,937 & $<0,001$ \\
\hline MK5 & $<---$ & M_K & 0,710 & 1 & & & \\
\hline MK4 & $<---$ & M_K & 0,831 & 1,095 & 0,071 & 15,367 & $<0,001$ \\
\hline MK3 & $<--$ & M_K & 0,816 & 1,058 & 0,070 & 15,178 & $<0,001$ \\
\hline MK2 & $<--$ & M_K & 0,670 & 0,836 & 0,066 & 12,765 & $<0,001$ \\
\hline MK1 & $<--$ & M_K & 0,425 & 0,528 & 0,065 & 8,154 & $<0,001$ \\
\hline ME1 & $<--$ & M_E & 0,572 & 1 & & & \\
\hline ME2 & $<---$ & M_E & 0,658 & 1,102 & 0,104 & 10,549 & $<0,001$ \\
\hline ME3 & $<--$ & M_E & 0,718 & 1,209 & 0,108 & 11,166 & $<0,001$ \\
\hline ME4 & $<--$ & M_E & 0,773 & 1,332 & 0,114 & 11,658 & $<0,001$ \\
\hline ME5 & $<--$ & M_E & 0,771 & 1,339 & 0,115 & 11,646 & $<0,001$ \\
\hline ME6 & $<--$ & M_E & 0,720 & 1,353 & 0,121 & 11,180 & $<0,001$ \\
\hline MT1 & $<---$ & M_T & 0,554 & 1,000 & & & \\
\hline MT2 & $<---$ & M_T & 0,714 & 1,234 & 0,085 & 14,477 & $<0,001$ \\
\hline MT3 & $<--$ & M_T & 0,836 & 1,500 & 0,133 & 11,284 & $<0,001$ \\
\hline MT4 & $<---$ & M_T & 0,781 & 1,402 & 0,127 & 11,005 & $<0,001$ \\
\hline MT5 & $<---$ & M_T & 0,615 & 1,120 & 0,117 & 9,596 & $<0,001$ \\
\hline MT6 & $<--$ & M_T & 0,520 & 0,939 & 0,110 & 8,537 & $<0,001$ \\
\hline MM1 & $<--$ & M_M & 0,719 & 1 & & & \\
\hline MM2 & $<--$ & M_M & 0,858 & 1,208 & 0,075 & 16,079 & $<0,001$ \\
\hline MM3 & $<---$ & M_M & 0,795 & 1,200 & 0,079 & 15,242 & $<0,001$ \\
\hline MM4 & $<---$ & M_M & 0,699 & 1,058 & 0,078 & 13,524 & $<0,001$ \\
\hline
\end{tabular}

$\beta_{0}$ : Standart yol katsayıları, $\beta_{1}$ : Standart olmayan yol katsayıları

\subsubsection{Yapısal Eşitlik Modeli ve Hipotez Testi}

Araştırma için kurulan modelin uygunluğunun değerlendirilmesi amacıyla ki-kare istatistiği RMSEA (Ortalama hata karekök yaklaşımı) ve GFI (Uyum iyiliği indeksi) değerleri dikkate alınmıştır. RMSEA değeri için; $0.05^{\prime}$ e eşit ve daha küçük değerlerin mükemmel uyuma, 0.08 ve altındaki değerlerin kabul edilebilir uyuma, 0.10'dan büyük değerlerde kötü uyuma karşılık gelmektedir. GFI değeri için ise; 0.95 ve üzeri mükemmel uyuma, 0.90 ve 0.94 arası kabul edilebilir uyuma karşılık gelmektedir. (Yılmaz vd., 2006: 176). Yine uyum iyiliklerinin almış olduğu değerler ile ilgili olarak Cengiz (2007), geliştirilen modelin gelişmekte olan bir alanı kapsaması halinde limit sınırlarının belirli oranlarda düşük kalmasının, örneğin 0,90 olması gereken bir değerin 0,85 düzeyinde olmasının da kabul edilebileceğini belirtmiştir. 


\begin{tabular}{|c|c|c|c|}
\hline \multirow{2}{*}{ Uyum İndeksleri } & $\begin{array}{c}\text { Mükemmel } \\
\text { Uyum Değerleri }\end{array}$ & $\begin{array}{c}\text { Kabul Edilebilir } \\
\text { Uyum Değerleri }\end{array}$ & $\begin{array}{c}\text { Elde Edilen } \\
\text { Uyum Değerleri }\end{array}$ \\
\hline $\mathrm{x}^{2}$ & & & 799,152 \\
\hline $\mathrm{df}$ & & & 282 \\
\hline $\mathrm{x}^{2} / \mathrm{df}$ & $\mathrm{x}^{2} / \mathrm{df} \leq 2$ & $2<\mathrm{x}^{2} / \mathrm{df} \leq 5$ & 2,834 \\
\hline $\mathrm{GFI}$ & $0,95 \leq \mathrm{GFI} \leq 1$ & $0,90 \leq \mathrm{GFI} \leq 0,95$ & 0,876 \\
\hline $\mathrm{AGFI}$ & $0,90 \leq \mathrm{AGFI} \leq 1$ & $0,85 \leq \mathrm{AGFI} \leq 0,90$ & 0,850 \\
\hline $\mathrm{NFI}$ & $0,95 \leq \mathrm{NFI} \leq 1$ & $0,90 \leq \mathrm{NFI} \leq 0,95$ & 0,869 \\
\hline CFI & $0,97 \leq \mathrm{CFI} \leq 1$ & $0,95 \leq \mathrm{CFI} \leq 0,97$ & 0,910 \\
\hline IFI & $0,97 \leq \mathrm{CFI} \leq 1$ & $0,95 \leq \mathrm{CFI} \leq 0,97$ & 0,911 \\
\hline TLI & $0,95 \leq \mathrm{TLI} \leq 1$ & $0,90 \leq \mathrm{TLI} \leq 0,95$ & 0,902 \\
\hline RMSEA & $0 \leq \mathrm{RMSEA} \leq 0,05$ & $0,05 \leq \mathrm{RMSEA} \leq 0,08$ & 0,065 \\
\hline
\end{tabular}

Yukarıdaki tablodaki gösterilen analiz sonuçları araştırma için kurulan modelin uyum değerlerinin kabul edilebilir sinırlar içinde olduğunu (RMSEA: 0,065, IFI: 0,911, GFI: 0,876, CFI: 0,910, TLI: 0,902 ve NFI: 0,869) göstererek, modelin yapısal olarak uygun olduğuna ilişkin yeterli kanitları sağlamaktadır.

Araştırma için kuruluna hipotezleri test amacıyla gerçekleştirilen yapısal eşitlik modeli analizi sonuçları Şekil 4'te ve Tablo 6'da gösterilmiştir.

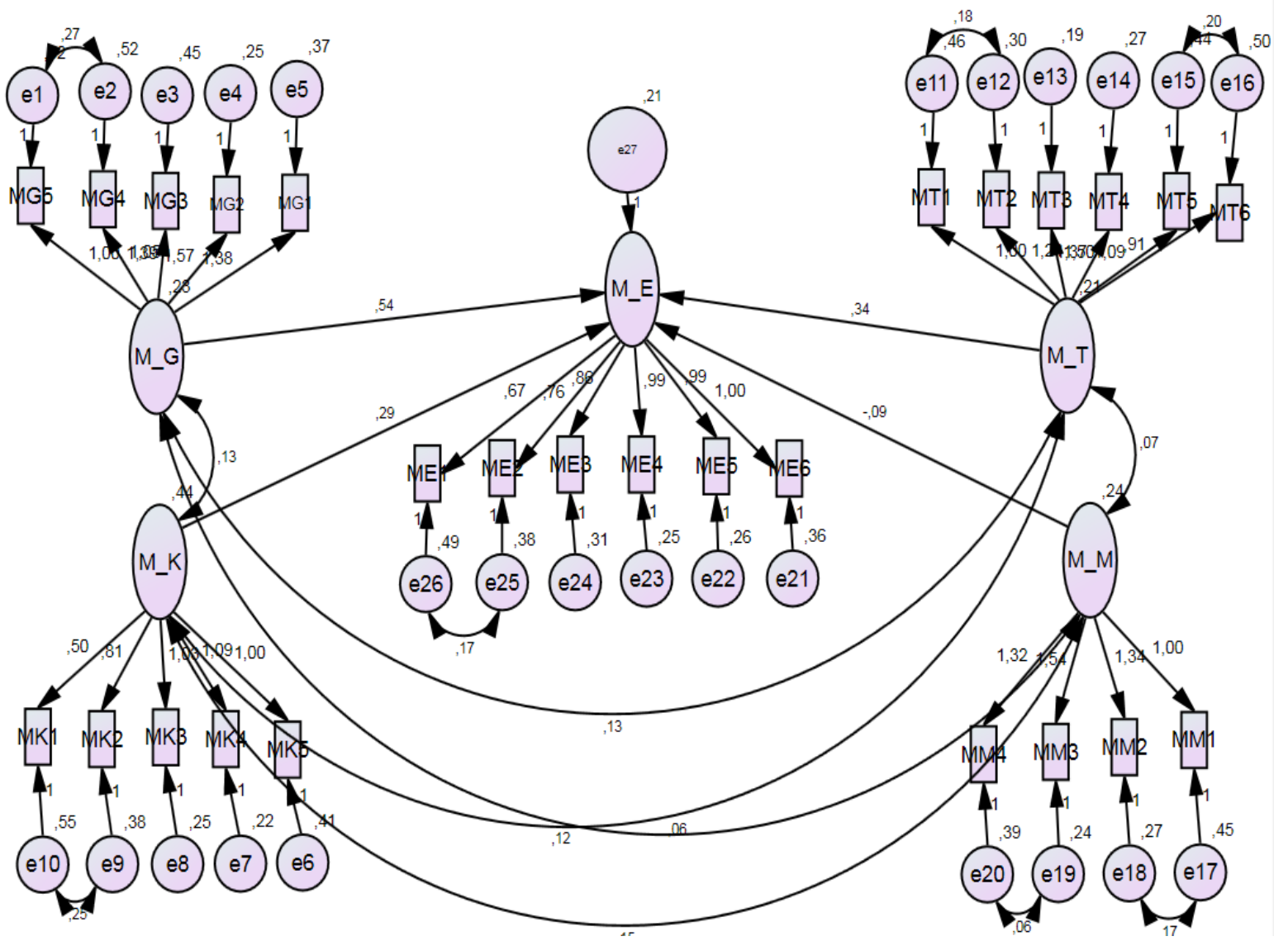

Şekil 4. Yapısal Eşitlik Modeli

Modeli kapsamındaki hipotez sonuçlarında $\mathrm{H}_{1}, \mathrm{H}_{2}$, ve $\mathrm{H}_{3}$ desteklenmiş, $\mathrm{H}_{4}$ ise desteklenmemiştir. "Marka güveninin marka evangelizmi üzerinde pozitif yönde etkisi vardır" hipotezi kabul edilmiştir $(\beta=, 540 ; p<, 001)$. "Marka tutkusunun marka evangelizmi üzerinde pozitif yönde etkisi vardır" hipotezi kabul edilmiştir $(\beta=, 340 ; p<, 001)$. "Marka kimliğinin marka evangelizmi üzerinde pozitif yönde etkisi vardır" hipotezi kabul edilmiştir $(\beta=, 292 ; p<, 001)$. "Marka memnuniyetinin marka evangelizmi üzerinde pozitif yönde etkisi vardır" hipotezi reddedilmiştir $(\beta=-, 092 ; p>, 010)$. 


\section{Tablo 6. Hipotez Testi Sonuçları}

\begin{tabular}{|c|l|c|c|c|c|c|}
\hline \multicolumn{2}{|c|}{ Hipotezler } & Estimate & S.E. & C.R. & P & Durum \\
\hline $\mathrm{H}_{1}$ & $\mathrm{ME}<---\mathrm{MG}$ & 0,540 & 0,106 & 5,079 &, $001^{*}$ & Kabul Edildi \\
\hline $\mathrm{H}_{2}$ & $\mathrm{ME}<---\mathrm{MT}$ & 0,340 & 0,086 & 3,934 &, $001^{*}$ & Kabul Edildi \\
\hline $\mathrm{H}_{3}$ & $\mathrm{ME}<---\mathrm{MK}$ & 0,292 & 0,056 & 5,209 &, $001^{*}$ & Kabul Edildi \\
\hline $\mathrm{H}_{4}$ & $\mathrm{ME}<---\mathrm{MM}$ & $-0,092$ & 0,080 & $-1,156$ & 0,248 & Reddedildi \\
\hline
\end{tabular}

\section{Sonuç ve Değerlendirme}

Tüketiciler ile bazı markalar arasında kuvvetli ilişkilerin mevcut olduğu geçmiş yıllarda yapılan çalışmalarda da kanıtlanmıştır. Yaptığımız araştırmanın asıl konusu olan marka evangelizmi çalışmamızda, tüketicilerin derinlemesine ilişki içinde olduğu markaya yönelik pozitif düşüncelere sahip olması, sahip olduğu bu düşünceleri isteyerek ve herhangi bir karşılık beklemeden çevresiyle paylaşması ve rakip gördüğü markalara yönelikte olumsuz ifadeler sergileme biçimiyle taraf olarak destek olma şeklinde kavramsallaştırılmıştır. Kısaca ifade etmek gerekirse, marka ile yoğun bir ilişki içinde olma, takip etme, kullanma ve markanın savunucusu olma şeklinde tanımlama yapabiliriz.

Literatür ve uygulayıcılar için oldukça yüksek bir öneme sahip olduğunu düşündüğümüz marka evangelizmini; tanıtmaya, ne ifade ettiğini belirtmeye, neden yüksek derecede öneme sahip olduğunu anlatmaya, hangi marka etmenlerinden (marka tutkusu, marka memnuniyeti, marka güveni ve marka kimliği) etkilendiğini saptamak için yapılan bu araştırmada, uygulamaya katılanların çoğunluğunu lisans düzeyinde eğitime sahip 29 - 39 yaş grubu arasındaki evli erkek memurlar oluşturmuştur. Çalışma için yapılan analizlerden faktör analizi sonucunda toplam beş faktör meydana çıkmıştır. Bu faktörler; marka evangelizmi, marka tutkusu, marka güveni, marka kimliği ve marka memnuniyetidir. Elde edilen faktörlerden sonra, kurulan hipotezleri test etmek niyetiyle yapısal eşitlik modeli kurulmuştur. Model sonuçları; marka tutkusunun $(\beta=, 340 ; p<, 001)$, marka kimliğinin $(\beta=, 292 ; p<, 001)$ ve marka güveninin $(\beta=, 540 ; p<, 001)$ marka evangelizmi üzerinde pozitif yönde etkilerinin olduğunu kanıtlamıştır. Ancak marka evangelizmi üzerinde marka memnuniyetinin $(\beta=-, 092 ; p>, 010)$ pozitif yönde etkisinin olduğu hipotezi, anlamlı düzeyde değere sahip olmadığı için kanıtlanamamıştır.

Çalışmamızda elde ettiğimiz sonuçları destekler nitelikte Matzler, vd. (2007), Doss (2010), Becerra ve Badrinarayanan (2013), Riorini ve Widayati (2015), Shaari ve Ahmad (2016), Mehran, vd. (2017), Yılmaz ve Aykaç (2018) ve Anggarini (2018), yapmış oldukları çalışmalarda marka evangelizmin çeşitli marka boyutlarından etkilendiği sonucuna ulaşmışlardır.

Matzler ve arkadaşları (2007) çalışmasında marka tutkusunun marka evangelizmi üzerinde pozitif etkisinin olduğunu bulmuşlardır. Doss (2010) yaptığı çalışmasında tüketici ile marka kimliği ne kadar güçlüyse, marka evangelizminin de o kadar güçlü olduğunu kanitlamıştır. Marka güveni ve marka kimliğinin marka evangelizmi üzerindeki etkisini inceleyen Becerra ve Badrinarayanan (2013), tüketici marka ilişkilerinin marka evangelizmini etkilediği sonucuna ulaşmıştır. Marka güveni ve marka kimliği ile marka evangelizmi arasındaki ilişkiyi inceleyen bir diğer yazar olan Riorini ve Widayati (2015), bu iki marka değişkeninin marka evangelizmi üzerinde olumlu etkiye sahip olduğunu bulmuştur. Marka güveni ile marka evangelizmi arasında güçlü bir ilişkinin mevcut olduğunu ileri süren Shaari ve Ahmad (2016), yapmış oldukları araştırma sonucunda hipotezlerini destekleyecek kanıtlara ulaşmışlardır. Mehran ve meslektaşları (2017) da marka güveninin ve marka kimliğinin marka evangelizmi üzerinde önemli bir etkiye sahip olduğunu belirtmiştir. Marka imajının marka evangelizmi üzerindeki etkisinde marka güveninin aracı olduğunu ve marka güveninin doğrudan marka evangelimi üzerinde anlamlı etkisinin olduğunu belirten Yılmaz ve Aykaç (2018), analizlerinin sonucunda hipotezlerini doğrulayacak verilere ulaşmışlardır. Son olarak Anggarini (2018), yapmış oldukları çalışmasında marka memnuniyeti, tüketici-marka kimliği ve marka güveninin marka evangelizmi üzerinde olumlu etkiye sahip olduğunu ifade etmiştir.

Çalışmamızda marka memnuniyeti ile marka evangelizmi arasında bir ilişki bulunamamıştır. Doss (2010) yılındaki çalışmasında, çalışmamıza paralel olarak marka memnuniyeti ile marka evangelizmi arasında herhangi bir ilişki bulamamıştır. Tüketiciler markaya bağlı olabilir veya ürün 
sınıfına bağlı olabilir, bu nedenle markadan memnun olabilirler ancak tatminin ötesine geçen herhangi bir gerçek güçlü duyguya sahip olmayabilirler. Çalışmada kullanılan memnuniyet, tüketicinin isteklerini ve ihtiyaçlarını tatmin etmek olarak düşünüldüğ̈ünde, tüketicinin ihtiyacını gidermiş olması o markanın evangelisti olacağı anlamına gelmeyebilir.

Ortaya çıkan analiz sonuçlarına dayanarak, işletmelerin markalarına yönelik tüketicilerde olumlu düşünceleri oluşturma ve bu düşüncelere sahip olan tüketicileri de evangelist seviyelere çıkarabilmek için, onların markaya güven duymasını sağlayacak adımlar atmalı, markaya karşı olan sevgiyi tutkuya dönüştürmeli ve markayı tüketicilere aitmiş gibi hissettirerek marka kimliği oluşturmalı diyebiliriz. Yaptığımız çalışma ile marka boyutlarının ayrı ayrı öneme sahip olduğunu ve etkilerinin de ayrı ayrı olduğunu söyleyebiliriz. Markaya güven duyan tüketiciler, geçmiş deneyimlerinden yola çıkarak yapacakları işlemlerin ardından kendilerini daha emniyette hissederler ve bunun neticesinde rakip markalara yönelmeyi daha az düşünürler. Yine benzer şekilde tüketicileri rakiplere yönelmesini düşüren bir diğer hususu da marka tutkusuyla açıklayabiliriz. Çünkü tüketicilerin markaya tutku ile bağlı olması demek, o marka ile birlikte olmaktan, ona sahip olmaktan ve onu kullanmaktan oldukça mutlu ve memnun oldukları anlamina gelir ki, buda yeni ihtiyaçların ortaya çıkması durumlarında tekrar aynı markanın ilk akla geleceği anlamını taşır. Bir diğer boyut olan marka kimliğine baktığımız da, herhangi bir markaya aidiyet hissi duyan tüketicilerin o markayla bütünleştiğini, markanın elde edeceği başarıları kendilerinin elde etmiş oldukları başarılarıymış gibi görebildiğini ayrıca kendi markalarını rakip markalara karşı savunduklarını ifade edebiliriz. Bu düzeyde bir duyguya sahip tüketicilerinde yine rakip markaları tercih etmeyeceğini belirtebiliriz. Bütün bu boyutlardan yola çıkarak şunu belirtebiliriz ki, bir markaya yönelik bu şekildeki düşüncelere sahip tüketicilerin markanın evangelisti olması da muhtemeldir. Güven duydukları, tutkunu oldukları ve kendilerini onun bir parçasıymış gibi gördükleri markalarına karşı en büyük destekçi ve çok sadık müşteri olurlar. Tüm bu sonuçlardan dolayı, karşılıklı oluşturulacak sağlam bir bağ ile marka ile tüketiciler artık "biz" olurlar.

Sonuç olarak özetlemek gerekirse markaya karşı olan bağı, tutkuyu, sevgiyi ve saygıyı artırmak isteyen işletmeler, güven ve iletişimi sağlamlaştırarak marka evangelizmini oluşturabilir ve markanın yararına çalışacak gönüllü elçiler bulabilir. Bu şekilde işletmeler bilgi arayıcısı ve dağıtıcısı olacak tüketiciler elde edebilirler. Tüketiciler sahiplendikleri markalarını diğer markalardan farklı ve üstün gördükleri için, onu daha fazla sahiplenecek, daha değerli görecek ve daha fazla öneme sahip olduğunu düşünecektir. Gelecekte yapılması muhtemel çalışmalar, marka evangelizmini etkileyebilecek marka boyutları başlığı altında marka sadakati, marka imajı gibi daha farklı boyutları ele alarak incelemelerde bulunabilirler. Ayrıca yine gelecek çalışmalar rekabet ortamının yüksek olduğu farklı bir sektöre yönelebilir veya farklı bir şehirdeki tüketiciler örneklem olarak seçilerek elde edilen sonuçlar çalışmamız ile karşılaştırılabilir.

\section{Kaynakça}

Aaker, D. A. (1991). Managing Brand Equity: Capitalizing on the Value of a Brand Name. NY: Free Press, New York.

Ahmed, Z., Rizwan, M., Ahmad, M. \& Haq, M. (2014). Effect of Brand Trust and Customer Satisfaction on Brand Loyalty in Bahawalpur. Journal of Sociological Research, 5(1), 306-326.

Anggarini, L. (2018). Understanding Brand Evangelism and the Dimensions Involved in a Consumer Becoming Brand Evangelist. Sriwijaya International Journal of Dynamic Economics and Business, 2(1), 63-84.

Balıkçıŏlu, B. ve Oflazoğlu, S. (2015). Marka Evangelizmi, Benlik-Marka İmajı Uyumu ve Marka Sadakati İlişkisi Üzerine Ampirik Bir Araştırma. Tüketici ve Tüketim Araştırmaları Dergisi, 7(2), 19-45.

Becerra, E., P. \& Badrinarayanan, V. (2013). The Influence of Brand Trust and Brand Identification on Brand Evangelism. Journal of Product E Brand Management, 22(5/6), 371-383.

Brown, J. H. \& Alnawas, I. (2016). Service Quality and Brand Loyalty The Mediation Effect of Brand Passion, Brand Affection and Self-Brand Connection. International Journal of Contemporary Hospitality Management, 28(12), 2771-2794. 
Cengiz, E. (2007). Kar Amacı Gütmeyen Kurumlar Olarak Müzelerde Pazarlama Faaliyetleri: Pazarlama Karması Unsurlarının Müzelerde Müşteri Sadakatine Etkisine İlişkin Yapısal Bir Model Önerisi. Karadeniz Teknik Üniversitesi Yayımlanmamış Doktora Tezi, Trabzon.

Cestare, T. (2018). Understanding the Antecedents and Outcomes of Brand Evangelism in the Digital Environment. Doctoral Dissertation, Pace University, New York City.

Chafer, L., S. (1911). True Evangelism: Winning Souls Through Prayer. Kregel Publications

Chaudhuri, A. \& Holbrook, M. B. (2002). Product-Class Effects on Brand Commitment and Brand Outcomes: The Role of Brand Trust and Brant Affect. Brand Management, 10(1), 33-58.

Chen, N., Wang, Y., Li, J., Wei, Y. \& Yuan, Q. (2020). Examining Structural Relationship among Night Tourism Experience, Lovemarks, Brand Satisfaction and Brand Loyalty on "Cultural Heritage Night" in South Korea. Sustainability, 12(17). 6723.

Craig, J. B., Dibrell, C. \& Davis, P. S. (2008). Leveraging Family-Based Brand Identity to Enhance Firm Competitiveness and Performance in Family Businesses. Journal of Small Business Management, 46(3), 351-371.

Doss, S. K. (2010). Spreading the Good Word: Toward an Understanding of Brand Evangelism. Doctoral Dissertation, University of Texas Rio Grande Valley, Teksas.

Füller, J., Matzler, K. \& Hoppe, M. (2008). Brand Community Members as a Source of Innovation. The Journal of Product Innovation Management, 25, 608-619.

Ghodeswar, B. M. (2008). Building Brand Identity in Competitive Markets: A Conceptual Model. Journal of Product \& Brand Management, 17(1), 4-12.

Hajibabei, H. \& Esmailpur, H. (2018). Providing Marketing Strategies Based on Studying the Role of Passion toward Brand, Self-Expression and Self-Brand Integration in Building Brand Trust. Journal of Industrial Strategic Management, 3(1), 55-67.

Hsu, L. C. (2019). Investigating the Brand Evangelism Effect of Community Fans on Social Networking Sites Perspectives on Value Congruity. Online Information Review, 43(5). 842-866.

Jamshidi, D. \& Rousta, A. (2021). Brand Commitment Role in the Relationship Between Brand Loyalty and Brand Satisfaction: Phone Industry in Malaysia. Journal of Promotion Management, 27(1), 151-176.

Keller, K., L. (2012). Understanding the Richness of Brand Relationships: Research Dialogue on Brands as Intentional Agents. Journal of Consumer Psychology, 22(2), 186-190.

Kim, H. K., Lee, K. Y. \& Baek, W. Y. (2020). Effect of Celebrity Athlete Endorsement on Sporting Goods Consumers' Brand Passion and Loyalty. Social Behavior and Personality an International Journal, 48(5), 1-11.

Kuenzel, S. \& Halliday, S. V. (2008). Investigating Antecedents and Consequences of Brand Identification. Journal of Product \& Brand Management, 17(5), 293-304.

Lam, S. K., Ahearne, Y. K. \& Schillewaert, N. (2010). Resistance to Brand Switching When a Radically New Brand is Introduced: A Social Identity Theory Perspective. Journal of Marketing, 74(6), 128146.

Mabkhot, H. A. \& Salleh, S. M. \& Shaari, H. (2016). The Mediating Effect of Brand Satisfaction on the Relationship Between Brand Personality and Brand Loyalty: Evidence from Malaysia. Management Science Letters, 6, 87-98.

Mamesah, S., Tumbuan, W. J. F. A. \& Tielung, M. V. J. (2020). The Influence of Brand Identification and Brand Satisfaction of Smartphone Products on Brand Evangelism. Jurnal EMBA: Jurnal Riset Ekonomi, Manajemen, Bisnis dan Akuntansi, 8(1), 11-20.

Marticotte, F., Arcand, M. \& Baudry, D. (2016). The Impact of Brand Evangelism on Oppositional Referrals Towards a Rival Brand. Journal of Product E Brand Management, 25(6), 538-549.

Matzler, K., Pichler, E., A. \& Hemetsberger, A. (2007). Who is Spreading the Word? The Positive Influence of Extraversion on Consumer Passion and Brand Evangelism. 2007 AMA Winter Educators' Conference Marketing Theory and Applications, 25-32.

Mehran, M. M., Kashmiri, T. \& Pasha A. T. (2017). Effects of Brand Trust, Brand Identification and Quality of Service on Brand Evagelism: A Study of Restaurants in Multan. Journal of Arable Crops and Marketing, 2(1), 7-22. 
Pourazad, N., Pare, V. \& Saniee, A. (2015). Brand Passion: What Would Customers Do for Their Favourite Brands. In Melbourne International Business and Social Science Research Conference, 1-7.

Pusa, S \& Uusitalo, L. (2014). Creating Brand Identity in Art Museums: A case Study. International Journal of Arts Management, 17(1), 18-30.

Rather, R. A. (2018). Investigating the Impact of Customer Brand Identification on Hospitality Brand Loyalty: A Social Identity Perspective. Journal of Hospitality Marketing \& Management, 27(5), 487513.

Riivits-Arkonsuo, L., Kaljund, K. \& Leppiman, A. (2014). Consumer Journey from First Experience to Brand Evangelism. Research in Economics and Business: Central and Eastern Europe, 6(1), 5-27.

Riorini, S. V. \& Widayati, C. C. (2015). Brand Relationship and Its Effect Towards Brand Evangelism to Banking Service. International Research Journal of Business Studies, 8(1), 33-45.

Shaari, H. \& Ahmad, I. S. (2016). Brand Evangelism Among Online Brand Community Members. International Review of Management and Business Research, 5(1), 80-88.

Smilansky, S. (2009). Experiential Marketing: A Practical Guide to Interactive Brand Experiences. Kogan Page Ltd., Philadelphia.

Song, H., Li, G., Veen, R. V. D. \& Chen, J. L. (2011). Assessing Mainland Chinese Tourists' Satisfaction with Hong Kong Using Tourist satisfaction Index. International Journal of Tourism Research, 13, 82-96.

Srivastava, R. K. (2011). Understanding Brand Identity Confusion. Marketing Intelligence E Planning, 9(4), 340-352.

Sung, Y. \& Kim, J. (2010). Effects of Brand Personality on Brand Trust and Brand Affetct. Psychology $\mathcal{E}$ Marketing, 27(7), 639-661.

Tran, V. D., VO, T. N. L. \& DINH, T. Q. (2020). The Relationship Between Brand Authenticity, Brand Equity and Customer Satisfaction. Journal of Asian Finance, Economics and Business, 7(4). 213-221.

Yıldız, S. ve Avcı, İ. (2019). Tüketici Temelli Marka Değerinin Taklit Markalı Ürün Algısı Üzerindeki Etkisi, Bingöl Üniversitesi Sosyal Bilimler Enstitüsü Dergisi, 9(17), 189-214.

Yılmaz, A. ve Aykaç, Ö. S. (2018). Marka İmajının Marka Evangelizmine Etkisinde Marka Güveninin ve Marka Sadakatinin Aracı Rolü. Uluslararası Hakemli Ekonomi Yönetimi Araştırmaları Dergisi, 16, 53-75.

Yılmaz, V., Çelik, H. E. ve Ekiz, E. H. (2006), "Investigation of the Factors Affecting Loyalty to Organization Through the Structural Equation Modeling: Example From Private and Public Banks." Anadolu University Journal of Marketing Studies, 2(2), s.171-184.

\section{Aim and Scope}

\section{Extended Abstract}

The aim of the study is to prove the positive effect of brand evangelism on brand trust, brand passion, brand identity and brand satisfaction by demonstrating the importance of promotion and insufficient knowledge. Consumers living in Erzurum province constitute the scope of the research. Consumers who participated in the study were first asked to write a brand that they saw as their positive spokesperson and shared their thoughts with their environment in the last six months, and then they were asked to answer the remaining questions by thinking about the brand they indicated.

\section{Methods}

One of the non-random sampling methods, "convenience sampling method" was used as the sampling method. Out of 450 questionnaires applied in total; As a result of eliminating missing, incorrect and false ones, 438 questionnaires were evaluated. In order to finalize the questionnaire form, to test whether the scales used in the questionnaire form are clear and understandable enough, and to eliminate any deficiencies that may arise, a pretest was applied to 20 people before starting the data collection. In line with the suggestions, criticisms and opinions obtained as a result of the pretest, the questionnaire form was reviewed and finalized. The questionnaire form of our study, where data was collected using face-to-face survey method, consists of 3 groups of questions. The question of consumers participating in the survey stating the name of any brand that they see as their positive spokesperson and shared their opinions with their environment in the last six months 
is in the first group. In the second group, there are expressions prepared in 5-Likert scale to measure the opinions of the consumers participating in the survey about brand evangelism and brand dimensions (brand passion, brand trust, brand satisfaction and brand identification). In the last group, there are questions prepared to determine the demographic characteristics of the consumers participating in the survey. Brand evangelism Cestare (2018), Riorini and Widayati (2015) and Matzler, et al. (2007), brand trust with 6 statements based on the studies of Becerra and Badrinarayanan (2013) and Riorini and Widayati (2015), brand identification in 5 statements, based on the studies of Becerra and Badrinarayanan (2013) and Doss (2010), the brand is passion Matzler, et al. (2007), and brand satisfaction was measured with 4 statements based on Doss (2010). The data collected through the questionnaire were analyzed using SPSS 20.0 and AMOS 20 statistics programs. A structural equation model was established by performing factor analysis on the data.

\section{Findings}

Participants in the survey; $52.5 \%$ are men and $47.5 \%$ are women. Most of the participants are officials $(23.7 \%)$ in the 29 - 39 age group (31.7\%), undergraduate $(32.6 \%)$, married $(53 \%)$, with income between $4001-6000 \mathrm{TL}(31.7 \%)$. As a result of the factor analysis performed for the study, a total of five factors were obtained. These factors are; brand evangelism, brand passion, brand trust, , brand satisfaction and brand identification. After the obtained factors, a structural equation model was established in order to test the formed hypotheses. Model results; has supported that brand trust $(\beta=, 432 ; p<, 001)$, brand passion $(\beta=, 359 ; p<, 001)$ and brand identification $(\beta=, 310 ; p<, 001)$ positively affect brand evangelism. However, the hypothesis that brand satisfaction $(\beta=-, 080 ; p>$ $, 010)$ positively affects brand evangelism was not supported because it did not have a significant value.

\section{Conclusion}

In support of the results we obtained in our study, Matzler et al. (2007), Doss (2010), Becerra and Badrinarayanan (2013), Riorini and Widayati (2015), Shaari and Ahmad (2016), Mehran, et al. (2017), Yılmaz and Aykaç (2018) and Anggarini (2018) concluded in their studies that brand evangelism is affected by various brand dimensions. Based on the results of the analysis, we can say that businesses should take steps to make them trust the brand, turn the love towards the brand into passion, and create a brand identification by making the brand feel like it belongs to the consumers, in order to create positive thoughts in consumers about their brands and to raise the consumers who have these ideas to evangelist levels. With the work we have done, we can say that brand dimensions have separate importance and their effects are also separate. Consumers who trust the brand feel more secure after the transactions they will take based on their past experiences and consequently, they think less about turning to rival brands. Similarly, we can explain another aspect that reduces consumers' turning towards competitors with brand passion. Because consumers are very happy and satisfied with being with the brand, owning it and using it, which means that the same brand will come to mind first when new needs arise. When we look at the brand identification, which is another dimension, we can express that consumers who feel a sense of belonging to a brand integrate with that brand, see the success of the brand as their own success and defend their brand against rival brands. We can state that consumers with this level of emotion will not prefer rival brands. As a result, businesses that want to increase the bond, passion, love and respect for the brand can create brand evangelism by strengthening trust and communication and find volunteer ambassadors to work for the benefit of the brand. In this way, businesses can obtain consumers who will be information seekers and distributors. Since consumers see the brands they own as different and superior to other brands, they will own it more, see it more valuable and think that it is more important. Possible future studies can examine different dimensions such as brand loyalty and brand image under the heading of brand dimensions that may affect brand evangelism. In addition, future studies may be directed to a different sector with a high competitive environment or the results obtained by selecting consumers in a different city as a sample can be compared with our study. 